\title{
ORGANIZATIONAL REFORM OF REGENCY/CITY ELECTION COMMISSIONS IN WEST JAVA
}

\author{
By \\ Abdal \\ Sunan Gunung Djati State Islamic University, Bandung \\ Email: abdal@uinsgd.ac.id
}

\begin{abstract}
Article Info
Article history:

Received May 19, 2021

Revised June 28, 2021

Accepted July 14, 2021

\section{Keywords:}

Reform

Efficiency

Effectiveness

General Election Commission

ABSTRACT

This study aims to explore organizational reform at the Regency/City General Election Commission in West Java, both with regard to the existence of Regency/City KPU as the organizer of the General Election. as well as during the term of office of the commissioner. This study uses qualitative methods, descriptive analysis, case study strategies with steps for selecting topics and cases, reading literature, formulating research focuses and problems, data collection, data refinement, data processing, data analysis, data analysis process, theoretical dialogue, triangulation. findings, and conclusions of research results. data collection by observation, interviews, documentation and focus group discussion (FGD). Data analysis was carried out through data reduction procedures, data display and conclusion drawing/verification. Based on the results of the study, it can be concluded that the existence of the Regency/City General Election Commission is still needed as the organizer of the general election at the regional level; that there must be a change in the organization of the Regency/City General Election Commission in relation to the term of office of the commissioner from five years to 1.5 years for budget efficiency and performance effectiveness.
\end{abstract}

This is an open access article under the CC BY-SA license.

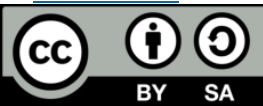

\section{Corresponding Author: \\ Abdal \\ Sunan Gunung Djati State Islamic University, Bandung \\ Email: abdal@uinsgd.ac.id}

\section{INTRODUCTION}

Indonesia is one of the countries that adheres to the notion of democracy, its implementation is proven by the existence of General Elections as a necessity. Through elections it will be possible to be elected, recruited, and formed as well as state leaders and representatives of the people who will work to represent and on behalf of the people's interests. To arrive at such ideal conditions, elections must be held democratically.

A democratic election has at least five requirements as stated by Asmawi (2009), namely: First, the election must be competitive. Second, elections must be held periodically. Third, elections must be inclusive. Fourth, voters should be given the freedom to consider and discuss their alternative choices in a free atmosphere, not under pressure, and with access to broad information. And fifth, an impartial and independent election organizer. Regarding the latter, Marwani wrote as follows: "The administration of elections is mostly a technical work. The technical work is coordinated by an election management committee. Therefore, the existence of an impartial, independent and professional election management committee will determine the course of a democratic election process. If the organizer is part of a ruling political party, or comes from a political party participating in the election, then the principle of impartiality is not fulfilled. Automatically the value of democratic elections is also not fulfilled."

Thus, the success and failure of the implementation of the General Election is highly dependent on how the EMB works objectively and professionally on the one hand. At the same time, the 'black-and-white' election results 
are also very dependent on how the election management body works based on the principle of impartiality/neutrality/independence or works non-neutrally/in favor of a particular subject.

Therefore, the government has created an institution that if it is possible to conduct an election in an objective/democratic manner so that from the election process it can actually present the elected people who are in accordance with and reflect as much as possible the wishes of the people. In order to fulfill this, the government through the state constitution stipulates that the election organizers are listed in the constitution, namely Chapter VIIB Article 22E of the Third Amendment of the 1945 Constitution which was stipulated on November 9, 2001. Article 22E, among others, contains the following provisions:

(1) elections are held every five years;

(2) elections are held to elect members of DPR, DPD, president/vice president, and members of DPRD;

(3) elections are held by a General Election Commission which is national, permanent and independent.

Based on the provisions of the Constitution, it can be stated that the organization for organizing elections in Indonesia is the General Election Commission (KPU) which is national, permanent and independent. This means that the Indonesian Constitution has stated the importance of the existence of an election management body, and ultimately requires the establishment of a national, permanent and independent KPU, which is then given the task and authority to carry out democratic elections. Thus, the 1945 Constitution has given the KPU a legal-constitutional position as a "state institution" in charge of holding elections.

However, the formation of the organization must also pay attention to the effectiveness and efficiency of the institution. As is the case with the Regency/City General Election Commission, which currently has its duties and functions only as an executor of policies made by the Central General Elections Commission. Because on the policy side it is centralized.

Based on this, the existence of the Regency/Municipal KPU should be reviewed, especially in the term of service of the commissioners, should it be five (5) years as the Central KPU or should it be different? In this regard, there is a bureaucratic reform agenda for the General Elections Commission to improve the organization which includes 8 (eight) areas of change, including:

1) The right organization functions that are able to support the achievement of the KPU's vision, mission, strategic goals and objectives with the support of clear and non-overlapping structures, work procedures and job descriptions as well as measurable performance indicators from the smallest unit to the largest unit;

2) Clear, effective, efficient and measurable work procedures and systems through the development of SOPs and an integrated e-government information system with various main applications required by work units and stakeholders;

3) The decline in laws and regulations issued by the General Secretariat of the KPU that are disharmony and overlap with other laws and regulations;

4) Improving the quality and competence of HR personnel supported by a reliable HR management system, from planning employee needs, recruitment systems, formation and placement, career patterns and reliable personnel information systems

5) A supervisory system that has an impact on the compliance and effectiveness of state financial management;

6) Improved accountability and performance of work units;

7) Improving the quality of public services embodied in minimum service standards and stakeholder involvement in service improvement; and

8) Changes in mindset and work culture of employees manifested in increasing employee professionalism, high performance, clean and free of KKN, able to serve the public and uphold the code of ethics of the state apparatus.

Based on the agenda, the writer sees that there is something lacking in the reform agenda, namely regarding the term of service of the commissioners, especially at the Regency/City General Election Commission level related to the commissioners. This is the focus of the research carried out, also supported by the researcher who was a member of the commissioner at one of the Regency KPUs in West Java Province.

Demands for reform or change for the better occur in various lives, including changes in organizations. However, the changes that occur do not lead to better conditions, therefore efforts need to be made so that these changes lead to changes that are better than before. There are various reasons why organizations change, and there are many types of changes that can be implemented as in the opinion of Winardi (2013:3) changes that arise due to restructuring activities - re-engineering and e-engineering - Innovation and TQM (Total Quality Management).

Organizational reform is highly dependent on the policies made by the government. Policy principles are related to policy formulation and also related to policy issues. But of all the issues that develop, not all have the same priority for processing. This is determined by a screening process through a series of criteria. This is as stated by Said Zainal Abidin (2004: 56-59) that the criteria that can be used in determining one of the various policies: 
International Journal of Social Science (IJSS)

Vol.1 No.2 August 2021, pp: 85-92

ISSN: 2798-3463 (Printed) | 2798-4079 (Online)

DOI: https://doi.org/10.53625/ijss.v1i2.140

1) Effectiveness, measuring an alternative target that is achieved with an alternative policy can produce the desired final goal.

2) Efficient, the funds used must be in accordance with the objectives achieved.

3) Enough, a policy can achieve the expected results with existing resources.

4) Fair

5) Answered, the policy is made in order to meet the needs of a certain group or problem in society.

\section{RESEARCH METHOD}

This research on the Organizational Reform of the Regency/City Election Commission in West Java Province is a qualitative research, Denzin and Lincoln (1994: 2) define qualitative research as follows: Qualitative research is multimethod in focus, involving an interpretative, naturalistic spprosch to is subject matter. This means that qualitative researchers study in their natural setting, trying to make sense of interpret phenomena in terms of the meanings people bring to them. Qualitative research inolves the studied use and collection of a variety of empirical materials-case study, personal experience, introspective, live story, interview, observational, historical, interactional and visual texts-that describe routine and problematic moments and meaning in individuals' live.

The steps taken follow as stated by Rahardjo (2017: 15-17) as follows: 1) Selection of Themes, Topics and Cases. 2) Literature Reading. 3) Formulation of Research Focus and Problems. 4) Data Collection. 5) Data Refinement. 6) Data Processing. 7) Data Analysis. 8) Data Analysis Process. 9) Theoretical Dialogue. 10) Finding Triangulation (Confirmability). 11) Conclusion of Research Results.

\section{RESULT AND DISCUSSION}

Based on the 1945 Constitution (Third Amendment) Article 22E paragraph (5) General elections are held by an election commission that is permanent and independent in nature." Therefore, there is a discourse on the need to strengthen the position or existence of the General Election Commission (KPU) from the center to the regions in the constitutional structure. The very strategic role of the KPU in the circulation of power requires institutions that are not only independent, but have control of power over civilians and the military during the transition of government. In addition, it is also necessary to increase the capacity of human resources for election management. However, strengthening is still needed so that political contestation, especially in elections, runs fairly and equally.

The strengthening of the KPU's authority is also in line with the complexity of organizing elections in Indonesia. The KPU manages three types of elections, namely the presidential and vice presidential elections, legislative elections (DPR, DPD and DPRD), regional heads and deputy regional heads (governors, regents and mayors). The election for President and Vice President in Indonesia with a direct election system is the largest in the world. Therefore, institutional strengthening and increasing resources are absolutely necessary in maintaining the existence of the KPU from the center to the regions. Although in reality the human resources are very lacking.

In terms of the existence of Regency/Municipal KPU, its position is so important in the implementation of elections, it is not surprising that the organization of the General Elections Commission is very vulnerable to being controlled by certain parties. Therefore, the organization of the General Elections Commission must be independent, independent, neutral from any pressure. This is to maintain the journey of Indonesia's democracy in giving birth to rulers who will take care of this country for the next five years.

The existence of Regency/City KPU at this time is still needed as an implementation of democracy. This agrees with the research of I Ketut S Lanang Perbawa in 2013 that the existence of the KPU in the electoral system based on the 1945 Constitution, has the authority and duty to realize people's sovereignty and democratic government, the contribution of the existence of the KPU to support the implementation of elections towards the realization of people's sovereignty and democratic government.

It is true that currently Regency/City KPU is successful in organizing general elections, but the researcher's analysis is that the success of Regency/Municipal KPUs in the implementation of General Elections both for the Presidential, Legislative and Regional Head Elections is not solely the success of the KPU, but this success is greatly supported by participation the community, both election participants, voters and ad hoc officers who are at the subdistrict level (PPK), village level (PPS) and at the RW/RT level (KPPS).

Regency/Municipal KPU in general election activities only recap the activities that have been carried out by adhock officers (PPK, PPS and KPPS) such as the following activities:

1) Updating voter data based on population data prepared and submitted by the Government by taking into account the

latest election and/or governor and regent/mayor election data and stipulating it as voter data. To validate the correctness of voter data, the updating of the data is carried out by an ad hoc officer, only to be determined by the Regency/City KPU. 
2) The implementation of voting is carried out at KPPS, where KPPS/TPS are in direct contact with voters, the resistance is very large. Meanwhile, KPU only recapitulates the results of each KPPS/TPS. If there are problems at the TPS, then during the recapitulation there will be problems.

Based on this, the researcher emphasizes that the existence of the Regency/City General Election Commission is still needed as the organizer of the general election, however, changes are still needed, so that in the implementation of the general election there are no problems. As has happened in several areas, it has resulted in legal cases and even dishonorable dismissal of the commissioner.

Based on this, a change in the organization of the Regency/City General Election Commission becomes a necessity by using the strategy as stated by Bernadin and Russel (1998:210). Reorganization is a review or refocusing of the core competencies (core competition) of the organization concerned.

Furthermore, with regard to the organizational reform of the Regency/Municipal General Election Commission, especially with regard to the term of office of the commissioners, it must be supported by an adequate regulatory framework, the institutional strengthening program of the General Elections Commission is also supported by human resources of election organizers with integrity. Until now, the human resources of the General Elections Commission (KPU) consist of secretariat employees and commissioners. Secretariat employees, especially at the regional (district/city) level, their employment status is divided into 3 (three), namely:

1) Employees with seconded status (DPK), meaning that DPK employees are civil servants from the Regional Government where the Regional General Election Commission (KPU) is located;

2) Employees with organic employee status, who are appointed and owned by the General Election Commission (KPU); and

3) Employees with honorary or non-civil servant status.

The commissioners are employees who have a term of service of 5 (five) years in 1 (one) period based on the results of the selection and can be re-elected in the next 1 (one) period.

With regard to the tenure of district/city level commissioners, the results of the study can be explained that optimally the performance of commissioners in Regency/Municipal KPU is only 1.5 years in relation to the preparation, implementation and completion of the General Election, be it the Presidential/Vice President Election, Governor/Deputy Governor or Mayor/Deputy Mayor or Regent/Deputy Regent. While the remaining 3.5 years there is no significant work. In fact, all activities are carried out by the secretariat. Thus, the term of office of the commissioner must be ad hoc (for 1.5 years) not 5 years. This is in the context of budget efficiency in providing compensation or commissioners' salaries/honoriums.

Furthermore, the researcher analyzed internal factors and external factors using a SWOT analysis model approach by looking at the factors of strength, weaknesses, opportunities, and threats.

Analyzing the organization, that the Regency/City KPU organization is the potential and/or strength of the organization. In general, the institutional structure of the Regency/City KPU has been able to support the tasks and functions it carries out. As for further analysis of the organizational or institutional potential that the Regency/City KPU organization has succeeded in demonstrating its independent institutional nature, free from intervention from any party, however, there are still Regency/City KPU members who are still tempted by the games of political parties and potential participants. This can be seen in the implementation of the election for the determination of the results of the recapitulation of votes in various regions. Whereas it must be done based on the principles of professionalism, integrity, transparency and accountability.

Regency/Municipal KPU organizations have tried to reposition their institutions through a bureaucratic reform program launched by the KPU since 2013 and the implementation of various public service innovations towards professional and independent election management organizations.

Each line within the Regency/City KPU organization has supported the implementation of the duties and functions of the KPU as the organizer of the Indonesian election. Every Regency/City KPU employee has clearly understood the duties and functions of the organization so that every employee has the same perception in achieving organizational performance.

Looking at the human resource aspect of Regency/Municipal KPU in general, there are several important points that become weaknesses of Regency/Municipal KPU as a public organization, that Regency/City KPU organizations do not yet have adequate human resources. This is an obstacle in the KPU institution which is national in nature. However, the strength of the organization can be given sanctions, both administrative and formal (civil) against any employee who violates the regulations. The provision of this sanction is strengthened by the existence of the Election Organizing Honorary Council (DKPP) whose task is to examine, hear, and decide on complaints or reports of alleged violations of the code of ethics committed by Regency/City KPU members. 
International Journal of Social Science (IJSS)

Vol.1 No.2 August 2021, pp: 85-92

ISSN: 2798-3463 (Printed) | 2798-4079 (Online)

DOI: https://doi.org/10.53625/ijss.v1i2.140

As for the results of further analysis on the strength of the HR aspects related to leadership, that the organizational leaders, namely the Chair and Commissioner of Regency/City KPUs have a strong vision to bring Regency/Municipal KPU to a better direction; Organizational leaders can create a conducive atmosphere for the creation of effective organizational communication and have the ability to manage organizational resources properly; Organizational leaders have strengthened mutual trust and respect among all elements of the organization; Organizational leaders strive to create a productive organizational work culture by enforcing discipline, integrity and commitment to all employees.

Another aspect that supports the organization of Regency/Municipal KPU is the Planning and Budgeting Aspect in improving organizational performance that in general the KPU has succeeded in planning activities and managing budgets in accordance with applicable regulations. The strength of planning and budgeting aspects is that in the process of planning activities and budgets, it is carried out by involving the active participation of all elements of the organization. Budget governance meets the principles of transparency and accountability. Budget management is carried out by applying Government Accounting Standards (SAP).

Analysis of the policy aspect of Regency/City KPU that in general Regency/Municipal KPU has implemented policies and procedures that are acceptable to all parties. Regency/Municipal KPU organizations attempt to identify, create and document work mechanisms/management. In addition, the organization reviews and improves the mechanism/management and carries out comparisons based on periodic evaluations and inputs from various stakeholders. Moreover, from a policy perspective, it is currently being carried out directly by the Central KPU. The KPU organization has succeeded in compiling SOP and making clear and easy-to-understand regulations.

Aspects of infrastructure support and Information Technology in general KPU requires adequate infrastructure support and appropriate information technology. Until now, almost 99\% of Regency/City KPU do not have buildings and warehouses, as well as support for appropriate information technology that is not optimal, but is available.

The results of research related to organizational restructuring of Regency/City KPU in West Java Province, if analyzed using the SWOT model approach. By looking at internal factors (related to strengths and weaknesses), it is possible to minimize weaknesses, and at the same time maximize strengths. Likewise with external factors (related to opportunities and threats), then when threats are minimized, opportunities can be enlarged.

Based on the analysis carried out, the key factors that become strengths, weaknesses, threats and opportunities can be identified related to the existence of the Regency/City General Election Commission and the Organizational Restructuring of the Regency/City General Election Commission in West Java as summarized in the following table:

Table 1.Summary of Internal and External Factor Analysis

\begin{tabular}{|l|l|}
\hline \multicolumn{2}{|l|}{ Internal } \\
\hline Strength & Weaknes \\
\hline - Mandate of the 1945 Constitution and the & Overlapping programs and activities between work \\
$\begin{array}{l}\text { Election Organizing Law (S1) } \\
\text { - Strong leadership commitment (S2) }\end{array}$ & units (W1) \\
- Bureaucratic Reforms that have been & Disproportionate employee workload (W2) \\
$\begin{array}{l}\text { launched (S3) } \\
\text { - Employees have the same perception of the }\end{array}$ & Performance management partiality (W4) \\
duties and functions of the organization & The monitoring system for budget management is \\
(S4) & weak (W5) \\
- Experience in organizing elections (S5) & Limited facilities and infrastructure (W6) \\
- KPU as a vertical organization (S6) & Utilization of information technology is not optimal \\
& (W7) \\
\hline & Inadequate human resources (S8) \\
\hline Peluang / Opportunity & \multicolumn{1}{|c|}{ Ancaman / Treat } \\
\hline
\end{tabular}

Journal homepage: https://bajangjournal.com/index.php/IJSS 


\begin{tabular}{|c|c|}
\hline 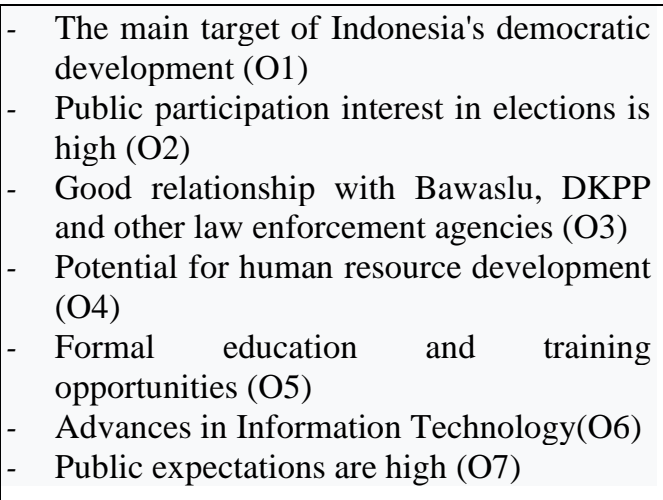 & $\begin{array}{l}\text { - Legislation on the electoral system is volatile (T1) } \\
\text { - Public opinion is easy to shift (T2) } \\
\text { - Demonstrations of dissatisfaction with the election } \\
\text { results which ended in chaos (T3) } \\
\text { - Claims on election results that are not based on } \\
\text { evidence (T4) } \\
\text { - Majority of HR with DPK status (T5) } \\
\text { - Distribution of logistics is constrained by } \\
\text { geographical conditions (T6) }\end{array}$ \\
\hline
\end{tabular}

Based on the identification of these key factors, the SWOT development strategies that can be taken are:

1. Strategy Strength - Opportunity (S-O): A strategy to take advantage of opportunities by utilizing the strengths of the organization.

a. Optimal utilization of Election Organizers for the realization of honest, fair, transparent, accountable and independent elections;

b. Coordinating with all stakeholders both at the preparation, implementation and post-election stages;

c. Improving the quality of human resources for Regency/Municipal KPU;

d. Build and utilize an integrated electoral information system.

2. Strategy Weakness - Opportunity (W-O): A strategy to take advantage of external opportunities that arise from the environment with the aim of overcoming weaknesses.

a. Arrangement of programs and activities in accordance with the main tasks and functions of the work unit;

b. Arrangement of employee duties in accordance with the analysis of positions and workloads;

c. Carry out internal coordination between related work units to improve KPU performance;

d. Optimizing the monitoring system and internal control over budget management;

e. Technical guidance on the implementation of SOPs;

f. Optimizing the use of facilities and infrastructure in the implementation of electoral tasks.

3. Strategy Strength - Threat (S-T): Strategy to face and overcome threats by utilizing the strengths of the organization.

a. Strengthening cooperation and coordination in the implementation of elections with related institutions;

b. Socialization and publication of the implementation of the Election in an optimal and transparent manner;

c. Increased accountability for electoral performance;

d. Optimizing the utilization of human resources in the management of election logistics at the stages of planning needs, procurement, and distribution.

4. Strategy Weakness - Threat (W-T): A strategy to avoid threats to protect the organization from existing weaknesses in the organization.

a. Structuring the institutions and personnel of the KPU Commissioners, including the secretariat;

b. Strengthening cooperation and coordination in the implementation of elections with related institutions;

c. Optimizing coaching, supervising the implementation of the General Election;

d. Strengthening election logistics management institutions at the stages of planning needs, procurement, and distribution.

Based on the SWOT development strategy above, it can be used as a reference for the formation of a SWOT analysis to see the reality of organizational restructuring of the Regency/City General Election Commission as follows: 
International Journal of Social Science (IJSS)

Vol.1 No.2 August 2021, pp: 85-92

ISSN: 2798-3463 (Printed) | 2798-4079 (Online)

DOI: $\underline{\text { https://doi.org/10.53625/ijjss.v1i2.140 }}$

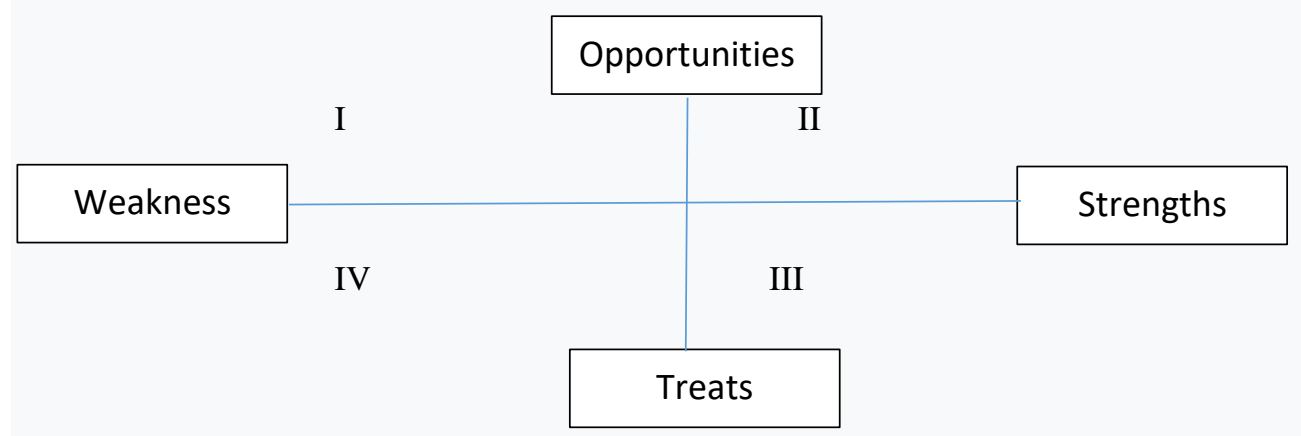

Picture 1. SWOT Analysis Diagram

The SWOT analysis model approach that can be done is in quadrant II that is based on the logic of understanding that is able to maximize strengths/strengths and opportunities/opportunities, and simultaneously minimize weaknesses/weaknesses and thretas/threats.

Practically, there are several considerations that need to be taken into account to reform the organization of the Regency/City General Election Commission, that seeing the opportunities the Regency/City KPU organization will continue to exist if the changes are supported by optimal human resources, support for facilities and infrastructure as well as effective and effective institutional strengthening efficient. However, the term of service for the commissioner is only 1.5 years.

\section{CONCLUSSION}

Based on the results of research and discussion on the organizational reform of the Regency/City General Election Commission in West Java Province, the researcher can conclude that the existence of the Regency/City General Election Commission is still needed as an implementer of general elections at the regional level.

The reforms needed in the organization of the Regency/City General Election Commission are related to human resources in positions as commissioners, a change in the term of service from 5 (five) years to ad hoc 1.5 years is required for reasons of efficiency in budget and effectiveness in performance.

\section{REFERENCES}

[1] Anderson, JE. 2001. Public Policy Making. New York Holt, Rinehart and Winston

[2] Bernadin, H. John., Russel, Blaine. 1998. Human Resource Management : An Experiential Approach. Singapure : McGraw Hill co Inc.

[3] Bennis, Waren dan Mische, Michael.1999. Reinventing Through Reengineering. (penerjemah Irma Andriani). PT Pustaka Binawan Pressindo, Jakarta.

[4] Black, James dan Champion, Dean. 2009. Metod dan Masalah Penelitian Sosial. PT. Rafika Aditama, Badung.

[5] Creswell, John W. 2013. Research Design: Pendekatan Kualitatif, Kuantitatif dan Mixed. Pustaka Pelajar Yogyakarta.

[6] Denzin dan Lincolin. 1994. Manual Coding In Kualitatif Reseach Metode.

[7] Mathis R.L dan Jackson J.H, 2006. Manajemen Sumber daya mnusia, Salemba Empat, Edisi Kesepuluh , Jakarta.

[8] Miles \& Huberman. 1994. Analisis Data Kualitatif. UI Press. Jakarta

[9] Rahardjo, Mudjia. 2017. Stsudi Kasus Dalam Penelitian Kualitatif: Konsep Dan Prosedurnya. UIN Malang.

[10] Sedarmayanti, 2002. Tata Kerja \& Produktivitas Kerja. Bandung : CV. Mandar Maju

[11] Winardi. 2000. Teori Organisasi. Alumni. Bandung

[12] Undang-Undang Dasar 1945 Hasil Amanden Ke IV.

[13] Undang-Undang Nomor 7 Tahun 2017 tentang Pemilihan Umum

[14] Jurnal :"Argumentium" volume 8 No. 2 Juni 2009 ISSN : 1412-1751

[15] Hasil Peelitian : I Ketut S Lanang Perbawa. 2013 :" Eksistensi Komisi Pemilihan Umum (KPU) Dalam Sistem Pemilu di Indonesia". Universitas Brawijaya. 
